\title{
水弁集約式波力発電システムにおける整流弁 (水弁) の損失特性 Characteristics of Loss at Rectifying Valve (Water-Valve) \\ in a Wave Power Conversion System with Water-Valve Rectifer
}

佐藤 英資 ${ }^{*}$ ・佐藤 栄司 ${ }^{* *}$ ・沢本正樹***

Eisuke Sato,Eiji Sato and Masaki Sawamoto

\begin{abstract}
This paper deals with a wave power generation system with water-valve rectifer. The water-valve rectifer converts oscillating air flow into steady air flow. The rectifier doesn't have a mechanical moving element, so the system is simple and maintenance free. However, because of the characteristic form of the rectifier, the loss in the rectifier is large and it is difficult to understand the characteristics of loss. In the paper, we indicate the characteristics by changing the cross-sectional area and the number of air pipes which affects the loss of water-valve rectifier.
\end{abstract}

Keywords : water-valve rectifier, wave power generation system, characteristics of loss

\section{1.はじめに}

数ある波力発電装置の中でも振動水柱型の波力発電装置においては，空気室内の水面変動によって生じる振 動空気流からどのように発電用タービンを回転させるかが重要な課題となっている．著者らは，水弁と称する 空気整流装置を組み込んだ波力発電装置について検討を進めてきた。この波力発電装置では振動空気流を一方 向空気流に整流する際に水并と呼ばれる流体力学的な特性を利用した整流弁を用いている，その概念図を図-1 に示す.

寄せ波時において, 水弁前後の圧力差が生じ排気側の水弁のみを空気流が通過する. 引き波時においては, 逆 に吸気側の水弁を空気流が通過する。このようにして一様空気 流が生み出され，それぞれ排気側吸気側の両方でタービンを回 転させることができる．このような水弁は機械的可動部を持た ないので，全体のシステムが比較的シンプルでありメンテナン スフリーであるという利点を持つ. しかし，このような独特の 并の形状により水弁での損失が比較的大きく，その特性がとらえ にくいといった欠点を持っている.

本研究では水弁の損失に影響を与えると考えられる鉛直管の 本数，断面積を変化させてその損失特性を明らかにすることを 目的亡する.

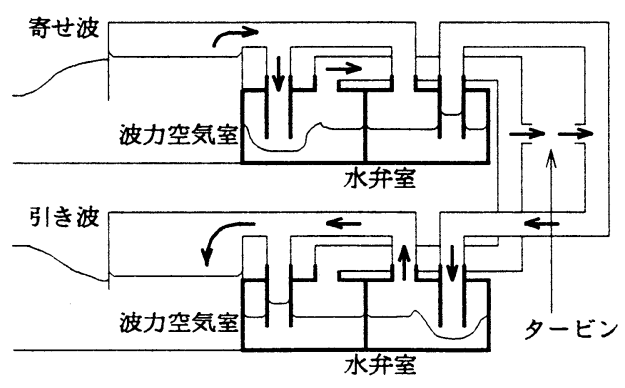

図-1 水弁式波力発電装置概念図

\section{2. 実験装置および実験方法}

\section{(1) 実験装置}

実験装置の概略図および測定点を図-2に示す，実験装置に おいて波力空気室内の水面の上昇，下降によって生じる振動 空気流をピストンから振動空気流を送り込むことによって再 現させた．この振動空気流が実験装置に送り込まれ，水弁に 上って一様空気流に恋換される，実験は，鉛直管径，鉛直管 本数, 鉊直管没水深, ピストン振幅, ピストン周期を変数と しておこなった。

ピストンの仕様は, 直径 $20 \mathrm{~cm}$ の円筒形で, 断面積は $314 \mathrm{~cm}^{2}$ であり，ゼロ位相時の体積は $8164 \mathrm{~cm}^{2}$ である. このピストン 4 本からの振動空気流は，流出管を経由して空気室に入る，流 出管の直径は $8 \mathrm{~cm}$ で，その断面積は $50.27 \mathrm{~cm}^{2}$ である.

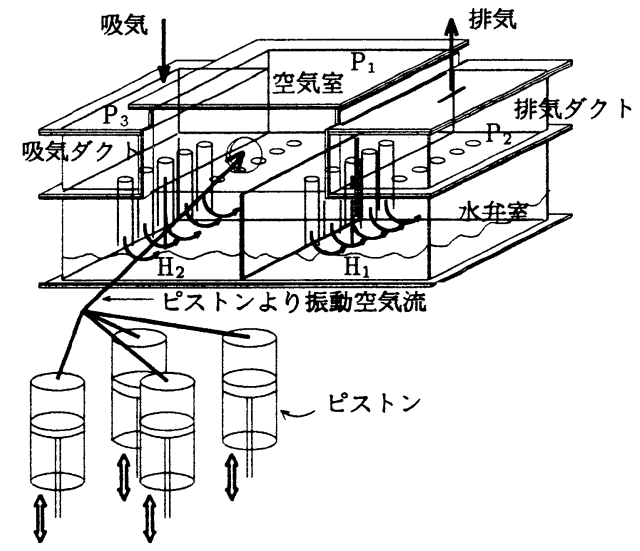

図-2 実験装置概略図

\footnotetext{
“学生会員 東北大学大学院 (广 980-77 仙台市青葉区党巻字青葉)

** 東北大学工学研究科土木工学専攻

***フェロー 東北大学工学研究科土木工学専攻
} 


\section{（2）実験方法}

測定は， $\mathrm{P}_{1}, \mathrm{P}_{2}, \mathrm{P}_{3}$ における圧力を歪式圧力計， $\mathrm{H}_{1}, \mathrm{H}_{2}$ における鉛直管内の水面変動を容量式波高計により 測定した. また，ピストンの振幅を振幅測定器によって測定した．測定は $50 \mathrm{~Hz}$ でサンプリングし， $\mathrm{AD}$ 変換後 パソコンのハードディスクに記録した. サンプリングは 90 秒間行い，そのデータに対してピストンの振幅のゼ ロアップクロスをとることにより周期を決定し，それをもとに 8 波から 17 波分に対して位相平均化処理を行い 解析に用いた。

実験ケースを表-1に示す．まず，ピストン周 期，鉛直管径を一定，ピストン振幅，鉛直管没 水深, 鉛直管本数を変数として実験を行い鉛直 管没水深の効果を知るための実験を行った．更 に，鉛直管没水深を一定，ピストン周期，ピス トン振幅, 鉛直管径, 鉛直管本数を変数として 実験を行いその損失特性について考察を行った.

\begin{tabular}{|c|c|c|c|c|}
\hline ピストン周期 & ピストン振幅 & 鉛直管径 $\mid$ & 鉛直管本数 & | 鉛直管没水深 \\
\hline $5 \mathrm{sec}$ & $2.5 \mathrm{~cm}$ & $3.0 \mathrm{~cm}$ & $\begin{array}{l}1 \text { 本 } \\
2 \text { 本 }\end{array}$ & \\
\hline $\begin{array}{l}7 \mathrm{sec} \\
9 \mathrm{sec}\end{array}$ & $7.5 \mathrm{~cm}$ & $\begin{array}{l}4.0 \mathrm{~cm} \\
5.5 \mathrm{~cm}\end{array}$ & $\begin{array}{l}3 \text { 本 } \\
4 \text { 本 } \\
5 \text { 本 }\end{array}$ & $1 \mathrm{~cm}$ \\
\hline
\end{tabular}

\section{3. 実験結果および考察}

\section{（1） 鉛直管没水深 $\mathrm{H}$ の効果}

ここで，鈶直管没水深 $\mathrm{H}$ と水弁の損失の関係を明らかにする. 図-3 にピストン周期 $7 \mathrm{sec}$, ピストン振幅 2.5 , $7.5,12.5 \mathrm{~cm}$ ，鉛直管径 $4 \mathrm{~cm}$ ，鉛直管本数 1 本の場合における鉛直管没水深 $\mathrm{H}$ 之圧力損失水頭 $\mathrm{h}$ の関係を示す. 圧力損失水頭 $\mathrm{h}$ は 1 周期間の平均值とし，排気時，吸気時で以下のような式を用いた.ここで， $\rho_{w}$ は水の密度， $g$ は重力加速度である.

$$
\begin{array}{ll}
\text { 排気時 } & : \quad h=\frac{1}{T} \int_{0}^{T} \frac{P_{1}-P_{2}}{\rho_{w} g} d t \\
\text { 吸気時 } & : \quad h=\frac{1}{T} \int_{0}^{T} \frac{P_{3}-P_{1}}{\rho_{w} g} d t
\end{array}
$$

ピストン振幅が一定であれば圧力損失水頭 $\mathrm{h}$ は鉛直管 没水深 $\mathrm{H}$ に比例して増加していることがわかる．この 場合, 比例定数は約 1 となり傾きがほぼ等しい直線で表 すことができる．他の実験ケースについても同様のこと がいえる.つまり，圧力損失水頭 $\mathrm{h}$ は鉛直管没水深 $\mathrm{H}$ と その他の部分 h'で表すことができる.

以後, 圧力損失水頭 $\mathrm{h}$ から鉛直管没水梁 $\mathrm{H}$ の効果を 引いた部分 h’についての損失特性を明らかにしていく.

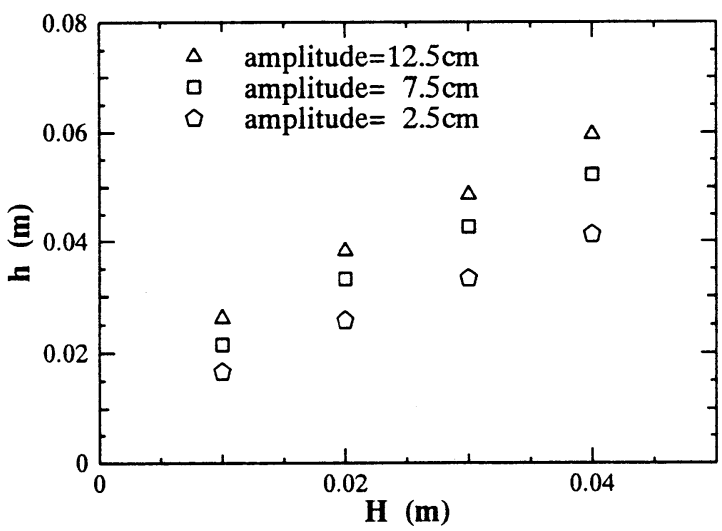

図-3 鉛直管没水深 $\mathrm{H}$ と王力損失水頭 $\mathrm{h}$ の関係

\section{(2) 鈶直管径 d の効果}

図-4にピストン周期 $5 ， 7,9 \mathrm{sec}$, ピストン振幅 $2.5,7.5,12.5 \mathrm{~cm}$, 鉛直管本数 1 本, 鉛直管径 $3,4,5.5 \mathrm{~cm}$ の 場合の圧力損失水頭を示す.ここで縦軸は圧力損失水頭 $\mathrm{h}$ から鉛直管没水深 $\mathrm{H}$ を引いた值 h'であり，横軸は鉛 直管内を通過する最大空気流速 Vである.

全体的に鉛直管径が大きくなると鉛直管内最大空気流 速が小さくなっており，また鉛直管内の最大空気流速が 等しい場合には鉛直管径が大きいほど圧力損失水頭が大 きくなっていることがわかる．この図では，圧力損失水 頭 h' を鉛直管内最大空気流速 V の関数として表してい るため鉛直管径が大きいほど圧力損失水頭 h' が大きく なっている. しかし，空気室に流入する空気流が同一の 場合には鉛直管径を大きくとることにより，鉛直管内最

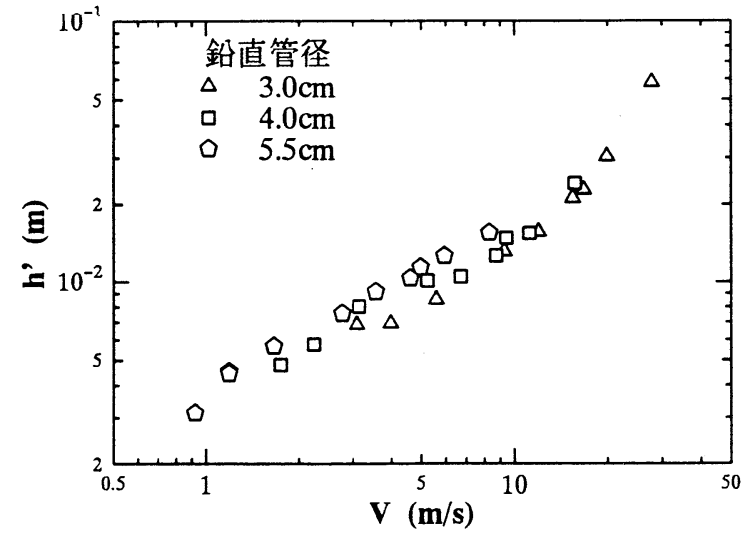
大空気流速が抑えられ，圧力損失を抑えることができる．図-4 鉛直管内最大空気流速 V と圧力損失水頭 $\mathrm{h}$ ' の関係 
図-5に図-4之同じ実験ケースにおける無次元空気流 速之無次元圧力損失水頭の関係を示す．ここで縦軸 $\mathrm{h}^{*}$ は $\mathrm{h}^{\prime}$ を鉛直管径 $\mathrm{d}$ で無次元化したものであり，横軸 $\mathrm{V}^{*}$ はV V $\sqrt{2 g d}$ で無次元化したものである. 無次元空気流 速 10〜13 を境にして損失特性が異なっていることがわ かる. これは高流速時には空気流は水中に途切れること なく風路を形成するが，低流速時には空気流は鉛直管端 部で大きく変動することが確認されている. 低流速時, 高流速時の空気の流れの形態がこのような損失特性の差 として現れていると考えられる.このような処理を行う ことにより, 圧力損失水頭 $\mathrm{h}$ 之鉛直管内最大空気流速 $\mathrm{V}$ の関係を明らかにすることができた.

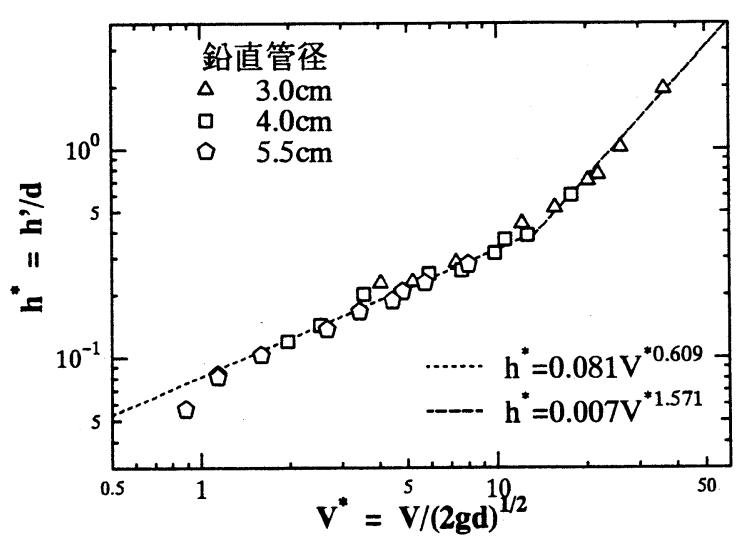

図-5 無次元空気流速と無次元圧力損失水頭の関係

\section{(3) 鉛直管本数の効果}

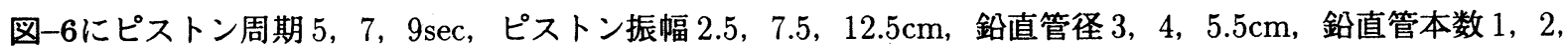
$3 ， 4 ， 5$ 本の場合の圧力損失水頭 $\mathrm{h}$ ～と鉛直管内最大空気流速 V の関係を示す. 鉛直管本数が 1 本と 5 本の場合 を黒塗りで表している．鉛直管本数が多いほど圧力損失水頭 h'が大きくなっているが，これは図-4同様に圧力 損失水頭 $\mathrm{h}$ 'を鉊直管内最大空気流速 V の関数として表しているためである．空気室に流入する空気流が同一の 場合には鉛直管本数を増やすことにより，鉊直管内最大空気流速が抑えられるため圧力損失を抑えることができ る. 図-7に無次元化した鉛直管内空気流速之圧力損失水頭の関係を示す．前節と同じように，縦軸は h' を鉛直

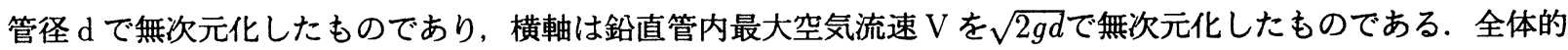
に鉛直管本数が多くなると鉛直管内空気流速が小さくなっており，それに伴って压力損失水頭も小さくなってい

る. また, 無次元空気流速之無次元圧力損失水頭の関係 は鉊直管本数ごとに異なっていることがかかる. この差 が鉛直管本数を複数にした場合の効果である.

図-8に無次元化した鉛直管内空気流速之圧力損失水 頭の関係を示す．鉛直管本数 $\mathrm{n}$ 本の場合，鉛直管本数 1 本に相当する鉊直管径は $\sqrt{n} \mathrm{~d}$ で表すことができる。し たがって，使用した鉊直管径 $\mathrm{d} に \sqrt{n}$ を掛けることによ り鉛直管径 1 本に相当する損失水頭を求めることができ る. 横軸はV を $\sqrt{2 g \sqrt{n} d}$ で無次元化したものであり, 縦 軸は h' $\sqrt{n} \mathrm{~d}$ で無次元化したものである. 図-8より， 圧力損失水頭 $\mathrm{h}$ 之鉛直管内最大空気流速 V の関係を明 らかにすることができた.

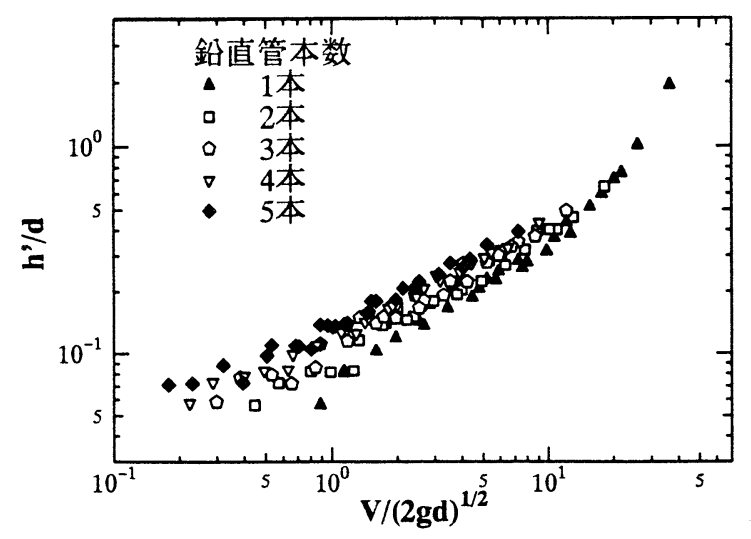

図-7 無次元空気流速と無次元圧力損失水頭の関係

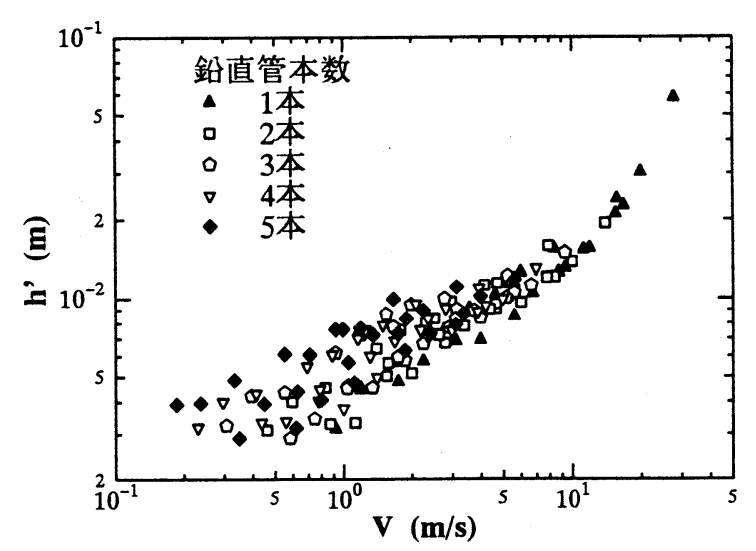

図-6 圧力損失水頭 $\mathrm{h}^{\prime}$ 之鉛直管内最大空気流速の V の関係

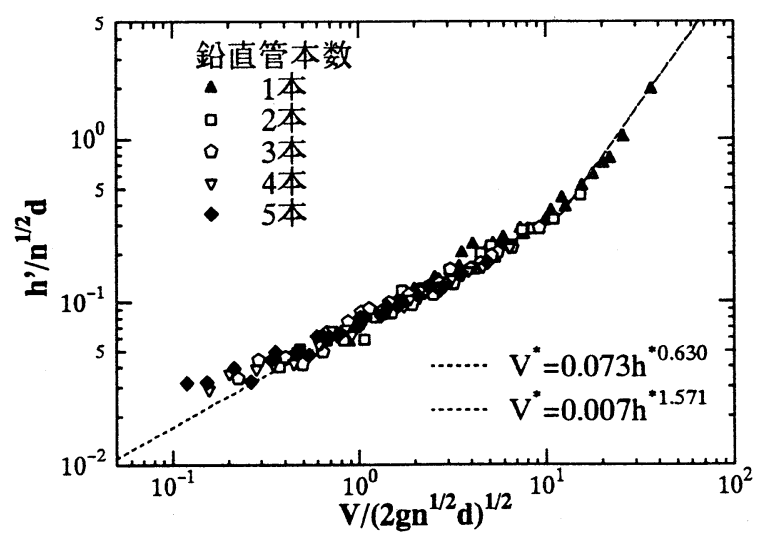

図-8 無次元空気流速と無次元圧力損失水頭の関係 


\section{（4）鉛直管全断面積の効果}

前節，前々節の結果より鉛直管径，鉛直管本数を変化させた場合の無次元鉛直管内空気流速と無次元圧力損失 水頭の関係が求められた．また，圧力損失水頭を抑えるには鉛直管径を大きくし，鉛直管本数を增やせばよい ということが明らかになった，つまり，鉛直管の全断面 積が大きければ圧力損失水頭が抑えられるということに なる.

ここで，鉛直管全断面積と圧力損失水頭の関係を求 める. 図-9にピストン振幅 $12.5 \mathrm{~cm}$ ，ピストン周期 $5 \mathrm{sec}$, の場合の鉛直管全断面積亡圧力損失水頭 h' の関係を示 す. それぞれの鉛直管径において鉛直管本数は鉛直管全 断面積が大きい方から $5,4 ， 3 ， 2 ， 1$ 本となっている. この図を見ると鉛直管全断面積と圧力損失水頭の関係は 一本の曲線で表すことができるといえる.つまり，鉊直 管径, 鉛直管本数が異なっていても圧力損失水頭は鉛直 管全断面積の関数で表すことができるということが明ら かになった.

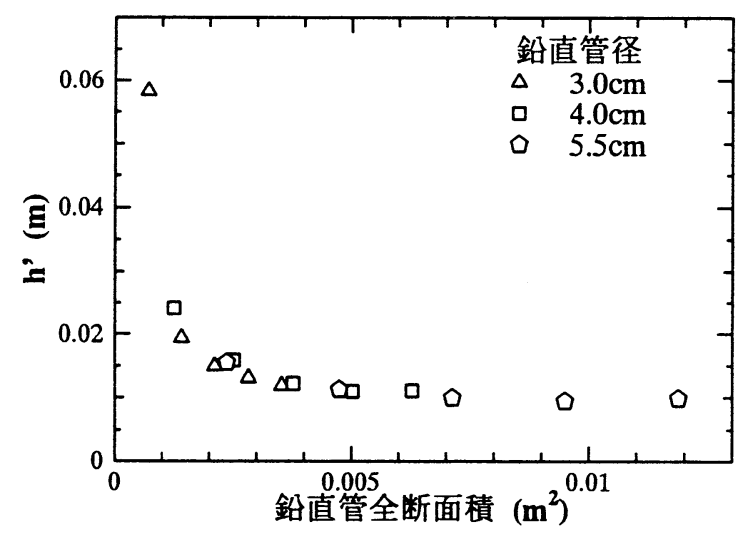

図-9 鉛直管全断面櫕と圧力損失水頭 h' の関係

\section{（5）水弁におけるパワー効率}

ここでは, 空気室と排気・吸気ダクト間のエネルギー差について比較を行った. 入力, 出力エネルギー EI, EP を以下の式により求めた.

$$
\begin{array}{ll}
E I=\frac{1}{T} \int_{0}^{T} P_{1} V_{1} d t & P_{1}, P_{2}, P_{3}: \text { 空気室, 排気, 吸気ダクト圧力 } \\
E P=\frac{1}{T} \int_{0}^{T} P_{2} V_{2}+P_{3} V_{3} d t & V_{1}, V_{2}, V_{3}: \text { 空気室, 排気, 吸気ダクト体積 } \\
& \mathrm{T}: \text { ピストン周期 }
\end{array}
$$

図-10にピストン周期 $5,7,9 \mathrm{sec}$, ピストン振幅 2.5 , $7.5,12.5 \mathrm{~cm}$, 鉛直管本数 1 本, 鉛直管径 $3,4,5.5 \mathrm{~cm}$ の 場合の無次元空気流速とエネルギー効率の関係を示す. 鉛直管径が同じ場合，鉛直管内空気流速が大きいほどエ ネルギー効率がよくなっている．また，鉛直管内空気流 速が同じ場合，鉛直管径が大きいほどエネルギー効率が よくなっている.

図-11にピストン周期 5，7，9sec，ピストン振幅 2.5 , $7.5,12.5 \mathrm{~cm}$ ，鉛直管径 $3 \mathrm{~cm}$ ，鉛直管本数 $1 ， 2 ， 3 ， 4,5$ 本の場合の無次元空気流速とエネルギー効率の関係を示 す. 図-10同様に鉛直管内空気流速が大きいほどエネル ギー効率がよい，また，鉛直管内空気流速が同じ場合， 鉊直管本数が多いほどエネルギー効率がよくなっている.

図-10，図-11よりエネルギー効率をアップさせるには ピストン周期を小さくしピストン振幅を大きくすればよ い.つまりピストン移動速度が大きくなればエネルギー 効率がアップする. 実際の海域での適用を考虑すると， 入射波の波高が大きく，周期が短いときにエネルギ一効 率がアップする. また, ピストン周期, ピストン振幅, 鉛直管本数が同じ条件の下では鉛直管径が大きいほど効 率がよく，ピストン周期，ピストン振幅，鉛直管径が同 じ条件の下では鉛直管本数が多い方が効率がよい.つま り，鉛直管全断面皘が大きい方が効率がよいということ になる。

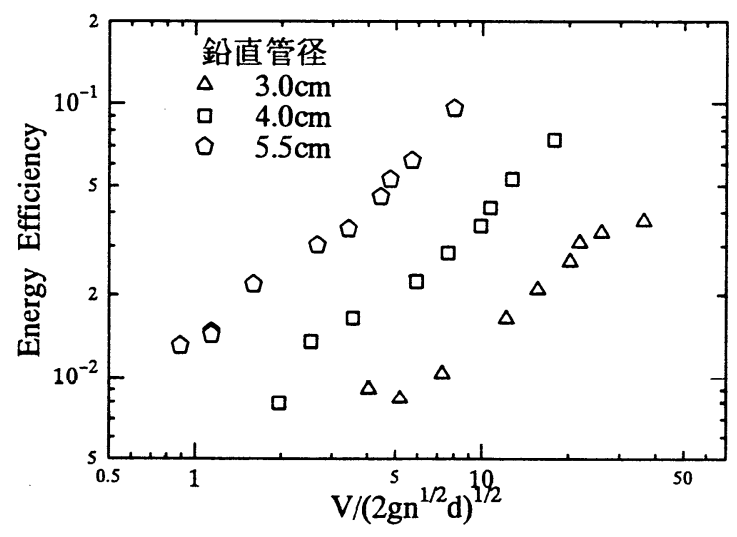

図-10 無次元空気流速とエネルギー効率の関係

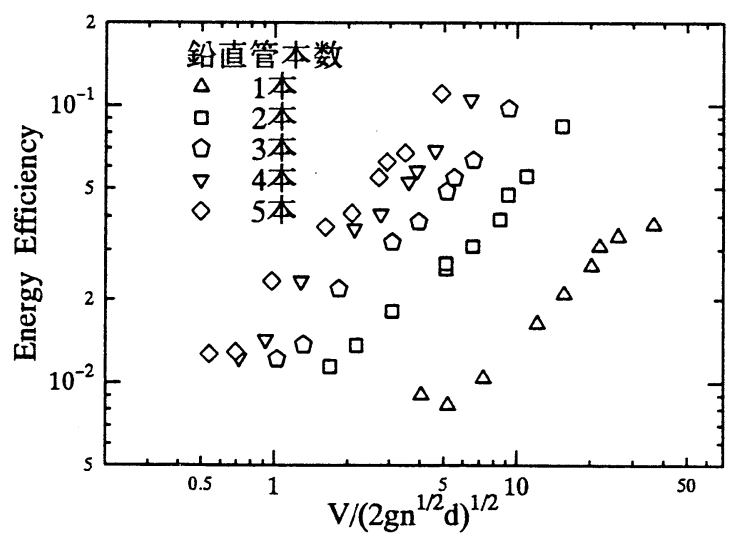

図-11 無次元空気流速とエネルギー効率の関係 
図-12にピストン周期 $5 \mathrm{sec}$ ，ピストン振幅 $12.5 \mathrm{~cm}$ ，鉛直管径 $3 ， 4 ， 5.5 \mathrm{~cm}$ ，鉛直管本数 $1 ， 2 ， 3 ， 4 ， 5$ の場 合，つまりピストン振幅，ピストン振幅が同じ場合の鉛直管全断面積とエネルギー効率の関係を示す. 図-12よ り，鉛直管全断面積が増加するほどエネルギー効率がアップする傾向にあるが，鉊直管全断面積 $0.003 \mathrm{~m}^{2}$ 付近を 境にしてその傾きが䌅やかになっていることがわかる. また，鉛直管本数を変化させて鉛直管全断面積を増加さ せた場合と鉛直管径を変化させて鉛直管全断面積を増加 させた場合の違いはないといえる．したがって，水弁の エネルギー効率をアップさせるには鉛直管全断面積をで きるだけ大きくすればよいということがわかった.

しかし，水并室断面積に比へて鉛直管全断面積が大き くなりすぎると，逆流時に鉛直管に入る水の体積と水弁 室内の水の体積が同程度となり, 逆止弁として正常に作 用しなくなることもあり得る．したがって，圧力漏れを 起こさない程度に鉛直管の断面積をできるだけ大きくと ることが必要である.

\section{（6）水面押し下げ深さの効果}

図-13にピストン周期 5，7，9sec，ピストン振幅 2.5 , $7.5,12.5 \mathrm{~cm}$, 鉛直管本数 1 本, 鉛直管径 $3,4,5.5 \mathrm{~cm}$ の 場合の無次元圧力損失水頭亡無次元水面押し下げ深さの 関係を示す．ここで，縦軸は前節同様に圧力損失水頭 $\mathrm{h}$ より鉛直管没水深 $\mathrm{H}$ の 2 倍, $2 \mathrm{H}$ を引いた h' 鉛直管径 $\mathrm{d}$ で無次元化したものである．また，横軸は空気流が鉛 直管を通過している際に水面を押し下げる深さ dh を鉛 直管径 $\mathrm{d}$ で無次元化したものである．また，図-14にピ ストン周期 $5,7,9 \mathrm{sec}$ ，ピストン振幅 $2.5,7.5,12.5 \mathrm{~cm}$, 鉛直管径 $3 \mathrm{~cm}$ ，鉛直管本数 $1 ， 2 ， 3 ， 4 ， 5$ 本の場合の無 次元圧力損失水頭之無次元水面押し下げ深さの関係を示 す.

鉛直管内を空気流が通過する際に，水弁室内の水面が 大きく乱される. したがって，水面押し下げ深さの值に 多少ばらつきが見られるが図-13，図-14より大まかな 傾向が読みとれる．水面押し下げ深さが大きいほど圧力 損失水頭が大きくなっていることがわかる. これは，水 面にはたらく空気流のエネルギーが大きくなるほど損失 が増加することを示している，これらの図より，鉛直管 径，鉛直管本数による違いは見られない，したがって， 無次元圧力損失水頭と無次元水面押し下げ深さの関係が 求められた.

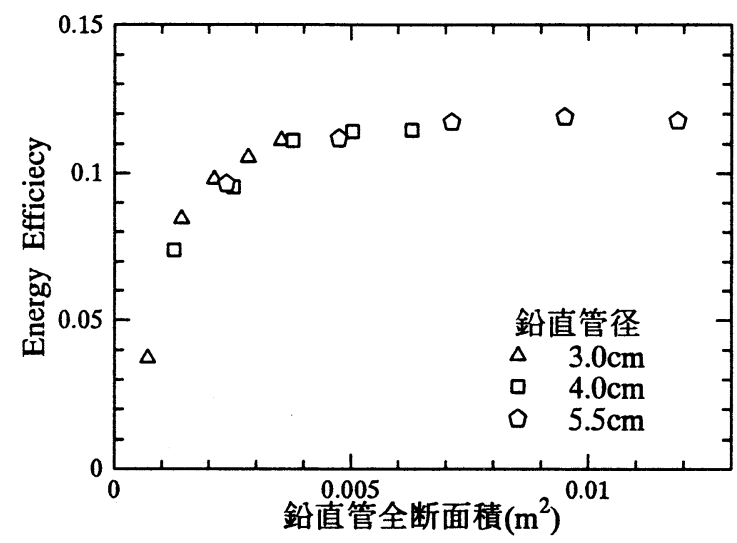

図-12 鉛直管全断面積とエネルギー効率の関係

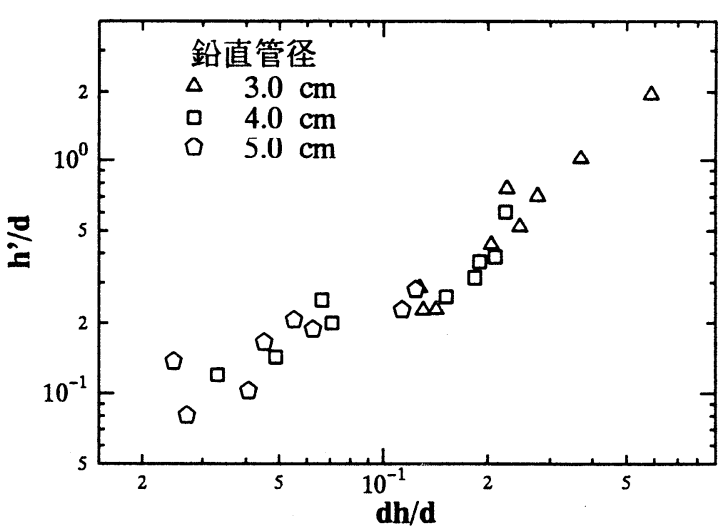

図-13 水面押し下げ深さと圧力損失水頭の関係

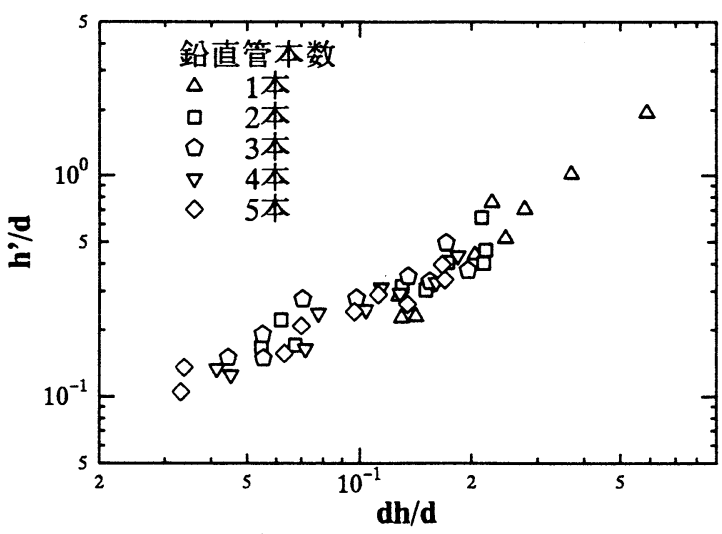

図-14 水面押し下げ深さと圧力損失水頭の関係 


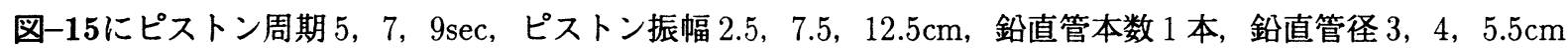
の場合の無次元水面押し下げ深さとエネルギー効率の関係を示す. また，図一16にピストン周期 $5,7,9 \mathrm{sec}$, ピ ストン振幅 $2.5,7.5,12.5 \mathrm{~cm}$, 鉛直管径 $3 \mathrm{~cm}$, 鉛直管本数 $1 ， 2 ， 3,4,5$ 本の場合の無次元水面押し下げ深さ とエネルギー効率の関係を示す.

水面押し下げ深さが大きいほどエネルギ一効率がよくなっている.これは，水面押し下げ深さが大きいほど 鉛直管内空気流速が大きくなることからも明らかである．また，水面押し下げ深さが同じ場合，鉛直管径が大 きく鉛直管本数が多いほど, つまり鉛直管全断面積が大きいほどエネルギー効率がよいことがわかった.

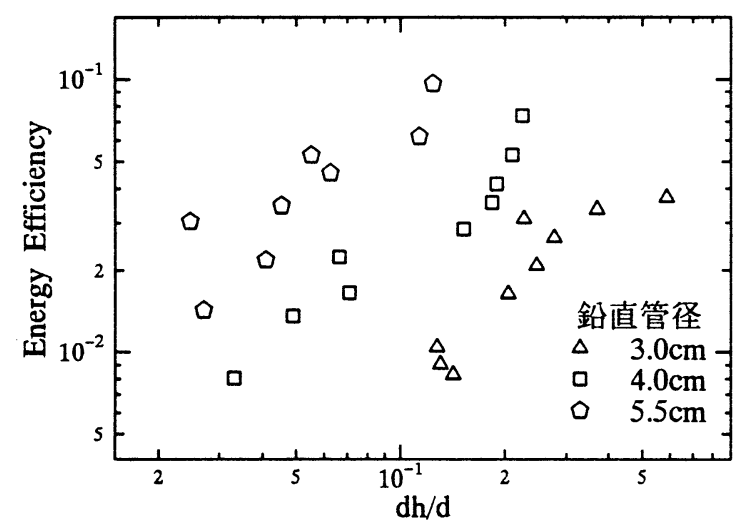

図-15 水面押し下げ深さとエネルギー効率の関係

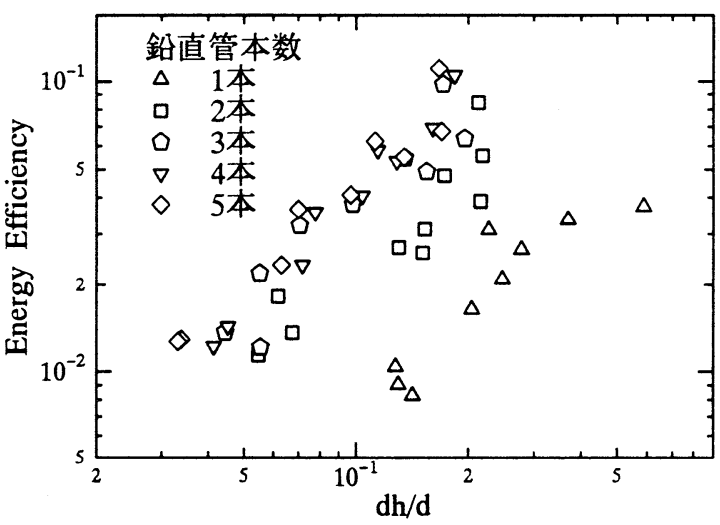

図-16 水面押し下げ深さとエネルギー効率の関係

\section{4. 結論}

今回の実験結果より, 以下のことが明らかとなった.

- 圧力損失水頭 h は, 鈶直管没水深 $\mathrm{H}$ とその他の部分 h’ の和で表すことができる.

- 圧力損失水頭 h' は鉛直管径が大きく，鉛直管本数が多いほど小さくなる．ここで圧力損失水頭 h'に支配 的なものは鉛直管全断面積である.

- 鉛直管径, 鈶直管本数を変化させた場合, 無次元鉛直管内空気流速と無次元圧力損失水頭の関係を求める ことができた。

- 鉛直管内を通過する空気流速が大きくなると圧力損失水頭は大きくなるがエネルギ一効率も大きくなる.

・水弁でのエネルギー効率を考えると鉛直管全断面積が大きいほど効率がよい.

・ 水面押し下げ深さが大きいほど圧力損失水頭が大きくエネルギー効率が大きい.

謝辞 : 本論文公表にあたり小川記念基金の補助を受けた，記して謝意を表します。

\section{参考文献}

1) 田中重人，沢本正樹：密閉型波力ケーソンの検討＼cjkstart海洋開発論文集，Vol.4，pp.283-288，1988.

2) 田中重人, 沢本正樹, 渡辺國也 : 密閉型波力ケーソンの水理特性 海洋開発論文集, Vol.5, pp.7-11, 1989.

3) 沢本正樹, 首藤伸夫, 渡部國也, 新嶋洋明 : 水弁を通過する空気流のエネルギー損失 土木学会論文集第 375 号, 1986.

4) 堀川清司 : 海岸工学 東京大学出版会

5) K.Watanabe, H.Nakagawa and M.Sawamoto: Study on pneumatic wave power conversion system with water valve rectifier Coastal Engineering in Japan, Vol.32, No.2, pp.257-269, 1989.

6) M.Sawamoto, D.Tsumune, K.Watanabe and M.Ohtomo : A new type wave power conversion system with water valve rectifier Proc. of Int. Symp. on Ocean Energy Development (ODEC), pp.281-287, 1993. 